\section{Resensi}

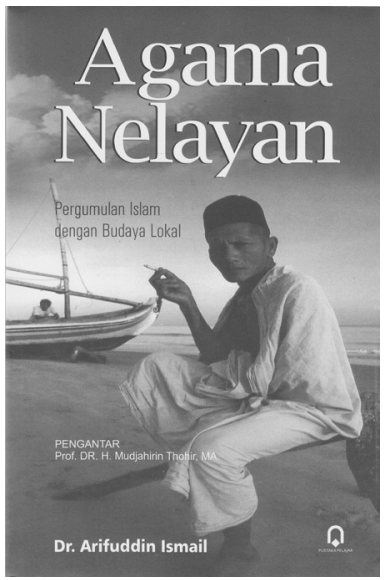

Judul Buku

Penulis

Penerbit

Tebal Buku

Idaman*

\title{
Agama Nelayan: Islam Lokal di Tanah Mandar
}

Dalam konteks ke-mandar-an, paling tidak hingga di era modern, Islam telah menjadi bagian prinsipil dalam keseluruhan aspek kehidupan etnis mayoritas ini di Sulawesi bagian Barat. Membaca Mandar, tak pelak, harus pula ikut membaca Islam, dalam hal ini bagaimana Islam menyatu atau mem-' pribumisasi' dalam struktur sosial dan budaya Mandar. Karya Arifuddin Ismail ini telah berupaya mensistesiskan sebuah kultur bahari, yaitu kultur nelayan dan Islam di Mandar. Sebagai sebuah karya riset, tentu dalam karya ini akan ditemukan idiom-idiom baru dalam diskurus Islam dan budaya lokal. Para pembaca akan diperkenalkan sebuah agama lokal yang disebut sebagai agama nelayan, sebuah idiom yang relatif baru dalam diskursus agama lokal di Indonesia, khususnya di Sulawesi Selatan. Jika selama ini, di Sulawesi Selatan, para peneliti sangat akrab dengan varian-varian agama lokal seperti Towani Tolotang, Aluk Todolo, Ammatoa Kajang, komunitas Bawakaraeng, dan seterusnya, maka kehadiran karya ini tentu menambah referensi atau informasi

(Staf Pengajar Fakultas Hukum Universitas Haluoleo, Kendari Dan Mahasiswa S3 Fakultas Filsafat Universitas Gadjah Mada) baru mengenai keberadaan agama (baca; Islam) nelayan di Tanah Mandar, khususnya bagi para peneliti dan penggiat agama lokal.

Persentuhan Islam dengan kebudayaan Mandar, dalam catatan Arifuddin Ismail, bermula ketika Islam masuk di wilayah tersebut pada awal abad XVII M atau abad $\mathrm{X} \mathrm{H}$, tepatnya $1610 \mathrm{M}$ yang dibawa oleh saudagar Arab Muslim, Syaikh Abdurrahim Kamaluddin, bersama para mubaligh dari Makassar. Sebelumnya, kehidupan tradisional suku bangsa Mandar masih dalam suasana hinduistik. Kehadiran Islam di tengah-tengah mereka membawa ajaran dan nilai baru. Pertemuan dua kebudayaan tersebut melahirkan akulturasi antara Islam dengan kebudayaan Mandar (tradisi lokal), yang kemudiaan membentuk suatu tatanan nilai tersendiri menjadi tradisi Islam lokal, seperti kebudayaan nelayan Pambusuang (hlm. 4). Penerimaan Islam bagi orang Mandar pun, khususnya masyarakat nelayan Pambusuang, disebabkan oleh beberapa alasan. Pertama, telah terdapat benih-benih religi pada masyaraat, seperti kepercayaan dan praktik ritual. Kedua, ajaran Islam dipandang memiliki kemiripan dengan kepercayaan lama yang mereka anut, seperti 
makhluk halus dan kekuatan gaib. Ketiga, nilai-nilai ajaran Islam dipandang sebagai kebenaran (hlm. 5).

Berdasarkan kenyataan tersebut, penulis buku ini hendak memperlihatkan bahwa inkulturasi Islam dalam peri-kehidupan masyarakat nelayan di Pambusuang dan Balanipa, Sulawesi Barat dapat teraplikasi dengan baik, tanpa memerlukan pemaksaan atau konflik, sebagaimana yang terjadi pada beberapa kebudayaan lain di negeri ini. ketika Islam telah terinternalisasi dalam kehidupan nelayan di Pambusuang, maka praktik-praktik lokal dapat tetap dihadirkan di tengah-tengah masyarakat Mandar yang beragama Islam. Di titik inilah sesungguhnya, penulis buku ini hendak mengungkapkan bahwa Islam bisa berjalan seiring dengan budaya lokal di Mandar, khususnya di kalangan nelayan Pambusuang, sebagaimana tampak pada ritual-ritual khusus bagi para nelayan di daerah ini.

Dalam kehidupan orang-orang Mandar, khususnya yang bermukim di wilayah pesisir, sangat intim dengan laut. Mereka menyebut laut dengan "sasiq", dan orang yang mencari penghidupan di laut disebut posasi. Sasiq atau hamparan laut dianggap tempat atau kawasan yang memiliki misteri atau rahasia. Laut bisa memberikan kehidupan, menawarkan berbagai kebaikan. Laut menjadi tempat mencari penghidupan, bahkan dianggap sebagai sumber penghidupan utama. Akan tetapi, terkadang juga laut memunculkan kegelisahan, bahkan malapetaka seperti kehancuran dan kematian (hlm. 122).

Seperti halnya dengan pelaut-pelaut Bugis-Makassar, para nelayan dan pelaut Mandar juga dikenal kepiawaiannya dalam menaklukkan laut. Biasanya, pelaut-pelaut Mandar menggunakan perahucadikyang saat ini mendunia, sandeq. Keakraban masyarakat nelayan atau pelaut di Pambusuang dengan kehidupan laut sangat kental, sehingga ada ungkapan yang popular di kalangan nelayan dan para pelaut, sebagaimana dicatat oleh penulis (hlm. 123)' "mua melo lambing sau dilolongan, da mupissalai lembong, apa lembong tu'u mipatada apa anu nadiakattai" (Jika hendak menyeberang ke suatu pulau, maka jangan menghindari gelombang, karena gelombang laut itulah yang bisa menghantarkan kita ke tempat tujuan).

Para nelayan di daerah ini meyakini bahwa laut memiliki 'penjaga'. Oleh karena itu, mereka diminta memperlakukan sang 'penjaga' dengan baik demi kebaikan para nelayan sendiri. Biasanya, para ponggawa lopi selalu mengingatkan, sebagaimana dicatat penulis (hlm. 124), "Mua nasauwi tau dzi sasiq dipacoai pappinaqditta, dipacoai toi kedzokedzota, daleqba mappapia anu mikkeallaq-allaq, battuanna anu andiang sitinaya nadzipogau", (Kalau hendak melaut, kita seyogyanya membenahi diri, memperbaiki perilaku, dan jangan membuat sesuatu yang aneh-aneh, artinya melakukan sesuatu yang tercela).

Hal menarik dalam karya ini adalah ternyata para ponggawa biasa memanfaatkan ilmu yang didapatkan dari para ulama di Pambusuang. Dalam penelitian penulis buku ini, ditemukan adanya pemahaman tasawuf yang berkembang di kalangan para nelayan atau para ponggawa, misalnya pemahaman dan keyakinan para nelayan tentang Tuhan khususnya paham Tallu Tammalaesang dan Dua Tammassarang. Ilmu tasawuf yang diperoleh dari ulama, misalnya oleh Imam Lapeo dianggap cocok dan nyaman. Para ponggawa, setelah mempraktikkan ilmu ini, biasanya merasakan adanya keteguhan dan ketenangan hati, khususnya ketika akan melaut (hlm. 129).

Di dunia laut orang Mandar di Pambusuang, ada dua sosok yang dianggap sebagai "penguasa" laut, yaitu Nabi Nuh dan Nabi Heller (Nabi Khidhir). Nabi Nuh ditempatkan pada posisi sebagai nabinya perahu. Keyakinan ini diinspirasi dari adanya kisah Rasul Allah tersebut yang membuat pertama kali perahu di musim kemarau, seperti yang termuat dalam Q.S. Hud [11]:38. Kedua nabi tersebut harus diagungkan dan selalu dihaturkan penghormatan khusus, terutama ketika melakukan aktivitas melaut. Nabi Nuh diyakini sebagi penguasa perahu, makanya setiap naik di perahu untuk 
turun ke laut, nakoda membaca basmalah kemudian disambung dengan bacaan: "Nabi Nuh di uluang; Nabi Ibrahim di tangnga; dan seterusnya. Setelah Nabi Nuh, Nabi Khidhir disebut sebagai pemimpin dan penguasa seantero lautan. Makhluk-makhluk halus lainnya dianggap sebagai anggota di bawah kekuasaan dan perintah Nabi Khidhir. Atas dasar inilah, para nelayan sebelum melaut, biasanya melakukan ritual khusus untuk menghormati kedua nabi ini. Selain itu, para Ponggawa Lopi mengharuskan dirinya untuk memiliki pengetahuan tentang paissangang posasiang (ilmu kenelayanan) yang di dalamnya terdapat pengetahuan ilmu gaib. Penguasaan ilmu ini dimaksudkan sebagai perangkat pelengkap yang harus ada pada diri seorang ponggawa (hlm. 131-133).

Peran vital lain yang dikenal dan sangat kental dalam dunia kebaharian orang Mandar adalah peran annangguru. Annangguru menjadi alat legitimasi ritual nelayan. Tanpa annangguru, ritual tidak akan mungkin berjalan. Dalam catatan penulis buku ini, ritual nelayan di PambusuangMandar terdiri dari tiga kategori, yakni ritual masa konstruksi, ritual masa produksi, dan ritual masa distribusi. Di ketiga ritual ini, peran sangat vital.

Pada tahap pertama yang dilakukan masyarakat nelayan di Pambusuang sebelum turun melaut adalah mempersiapkan perahu layar Sandeq atau kapal perahu motor. Jika belum memiliki kedua alat tersebut, biasanya harus membeli atau membuat sendiri. Semua prosesi sebelum turun ke laut dikategorikan sebagai rutual masa konstruksi. Bentuk ritual yang dilakukan pada masa konstruksi berupa penebangan pohon, pembuatan perahu, dan penurunan perahu baru ke laut. Sebelum dilakukan penebangan pohon, nelayan Mandar terlebih dahulu menentukan hari yang baik atau "waktu macoa". Setelah ditentukan hari yang baik, lalu diadakan penebangan pohon yang akan dijadikan sebagai perahu dengan didahului ritual oleh seorang ustadz, pande lopi, dan para pembantu yang bertugas menemani pande lopi. Tentu saja, dalam ritual semacam ini terdapat bahan-bahan sajian, seperti sokkol, kacang ijo, loka warangan, loka tira, dan loka manurung serta nasi lengkap dengan laukpauknya (hlm. 146-147).

Selain itu, satu bulan sebelum para nelayan turun ke laut, ponggawa lopi dan sawi secara bersama-sama menata atau memperbaiki perahu dan perlengkapan lainnya. Kegiatan tersebut meliputi mencat tubuh perahu atau kapal dan sebagainya, lalu dilanjutkan dengan ritual yang disebut dengan kuliwa. Ritual ini biasanya melibatkan - Ritual dilakukan di rumah ponggawa lopi dan di perahu dengan pembacaan Barzanji (hal. 152). Setelah dilakukan ritual sembari pembacaan barzanji di rumah dan di atas perahu, dilanjutkan dengan acara massissing posiq (menutup pusat perahu atau kapal). Acara ini dipimpin oleh sando lopi atau dukun perahu (hlm. 157-158). Kemudian pasa masa distribusi, ritual diadakan dalam bentuk mabbaca atau mabbaca-baca; tasyakuran.

Uraian panjang tentang ritual-ritual masyarakat nelayan Mandar di Pambusuang yang melibatkan, pembacaan barzanji dan ayat al-Qur'an dalam karya ini, memperlihatkan bagaimana pergumulan damai antara Islam denga tradisi lokal di kalangan nelayan di daerah ini. Bagi penulis buku ini, proses akulturasi nilai Islam ke dalam tradisi Mandar tentu saja tidak terlepas dari peran para ulama yang datang menyebarkan Islam. Dalam konteks ke-nelayan-an di Pambusuang, proses akulturasi Islam dengan tradisi lokal masyarakat di daerah ini dilakukan dengan cara dialog kebudayaan. Kebudayaan lokal yang bersumber dari keyakinan lokal tidak serta-merta diubah begitu saja. Tamsil yang relevan dicermati dalam fenomena ini adalah masih bertahannya tokoh spiritual lokal seperti sando lopi. Sando lopi ini (hlm. 178), masih memiliki ruang dalam ritual menurunkan perahu atau ritual penebangan kayu untuk pembuatan perahu. Sando lopi sebagai instrumen sosial lama tetap dipertahankan, hanya saja mantramantranya yang diucapkan telah mengalami proses transformasi dengan hadirnya idiom 
Islam, seperti bacaan basmalah. Apalagi, para sando lopi memang telah beragama Islam. Annangguru dan sando lopi memiliki fungsi ritual masing-masing.

Menurut penulis (hlm. 179), perubahan yang paling terasa dalam tradisi masyarakat nelayan di Pambusuang adalah perubahan orientasi dan agen kebudayaan. Orientasi teologis yang semula mengarah pada kekuatan spirit lokal "dibelokkan" ke arah teologi Islam. Idiom tentang kekuatan supranatural di laut juga ditukar dengan idiom Islam, seperti munculnya kepercayaan terhadap Nabi Khidhir sebagai penguasa laut menggantikan kekuatan laut yang semula diyakini bersumber dari jin laut. Agen kebudayaan juga berubah dari sando lopi ke annangguru. Annangguru merupakan istilah yang lahir dari proses akulturasi Islam menggantikan istilah ulama. Annangguru dianggap merepresentasikan cita rasa lokal tanpa kehilangan ciri sebagai seorang ulama. Annangguru merupakan pusat agensi transformasi kebudayaan masyarakat Pambusuang mengggantikan narasumber lokal yang semula dipegang oleh para sando.

Sebagai hasil penelitian untuk disertasi yang kemudian ditransformasi ke dalam bentuk buku, tentu karya ini memiliki keunggulan dari segi data dan narasi yang ditampilkan. Oleh karena itu, karya yang sangat informatif mengenai selukbeluk kemandaran, kenelayanan, dan proses akulturasi Islam dengan tradisi lokal masyarakat nelayan di Pambusuang, akan sangat bermanfaat bagi para peneliti, pembaca, dan penggiat agama lokal, khususnya di Sulawesi Selatan. 